\title{
Statistical modelling of equilibrium-line altitudes of Hintereisferner, central Alps, Austria, 1859-present
}

\author{
Hanns Kerschner \\ Institut für Geographie der Universität Innsbruck, Innrain 52, A-6020 Innsbruck, Austria
}

\begin{abstract}
Equilibrium-line altitudes (ELAs) are reconstructed for Hintereisferner, Tyrol, Austria, using temperature and precipitation records for the period from 1859 to the present. The basic idea is to calibrate simple statistical models using observations of the ELA over the period 1964-92. Results are compared with those of Kuhn's glacial- meteorological model of ELA fluctuations. Correlation coefficients between observed and predicted ELAs are 0.91 for the glacial-meteorological model and 0.98 for the multiple regression model. The calibrated model allows backward extrapolation of the ELA from the longer climatic records ("Austrian Temperature Series" since 1775; precipitation at Marienberg, South Tyrol, since 1858). ELAs after the glacier maximum of the 1850s were rather high until the 1870 s, when they show a trend towards lower values. The lowest values, about $200 \mathrm{~m}$ lower than the "1850" average, were finally reached in 1912-14. During the years 1907-26, the ELA of Hintereisferner was lower than the "1850" average in 13 out of 20 years. This led to the widespread glacier advance of the $1920 \mathrm{~s}$ in the Alps. After this, the ELA rose constantly, reaching its highest value in 1947. From the early 1950s until 1980 there was a trend towards lower ELAs again, which has been succeeded by a period of very high ELAs. The period from the late 1920 s to the early 1960 s was the longest period of almost constantly high ELAs since the middle of the 19 th century.
\end{abstract}

\section{INTRODUCTION}

The history of fluctuations of a glacier's equilibrium-line altitude (ELA) can give valuable insight into its behaviour, as ELA fluctuations are closely linked to mass-balance fluctuations (cf. Hoinkes, 1970). In this paper, an attempt is made to predict the ELA of Hintereisferner from simple climatic data with the help of multiple regression equations and the glacial-meteorological model of Kuhn (1981). The calibrated model then allows backward extrapolation of the glacier's ELA history from long records of temperature and precipitation.

At the equilibrium line of a glacier, accumulation is balanced by ablation. The ELA is determined only by the balance year's climatic conditions, whereas the form and re- action of the glacier tongue and the position of its snout are influenced by the prior history of mass balance and the flow of the glacier, which tends to mask the annual climatic conditions (cf. Kuhn, 1978). If climatic data of sufficient quality are available for a given year, the ELA of a glacier can, in principle, be predicted. This can be done either with a physical model relating accumulation to ablation, or with the help of statistical techniques (e.g. Kuhn, 1981; Ohmura and others, 1992). For both approaches, data representing ablation and accumulation are needed. In this paper, the "Austrian Temperature Series" (Böhm, 1992) and the preci-pitation records of Marienberg, SouthTyrol, are used as input data for the reconstruction of the ELA history of Hintereisferner.

Hintereisferner lies at the northern slope of the main divide of the Alps in the western Tyrol, Austria (Fig. 1). In

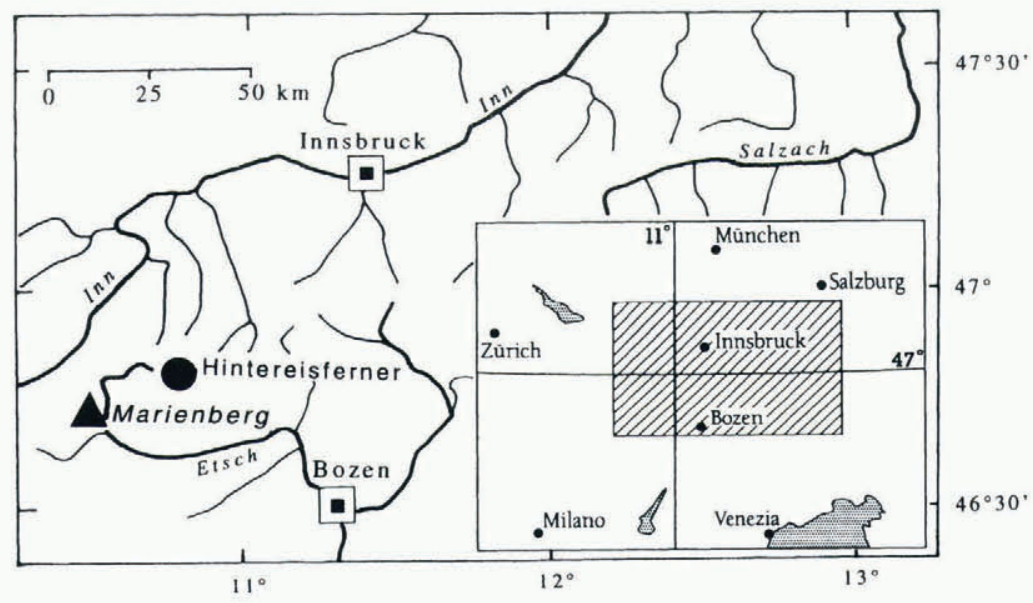

Fig. 1. Index map of Hintereisferner and Marienberg. 

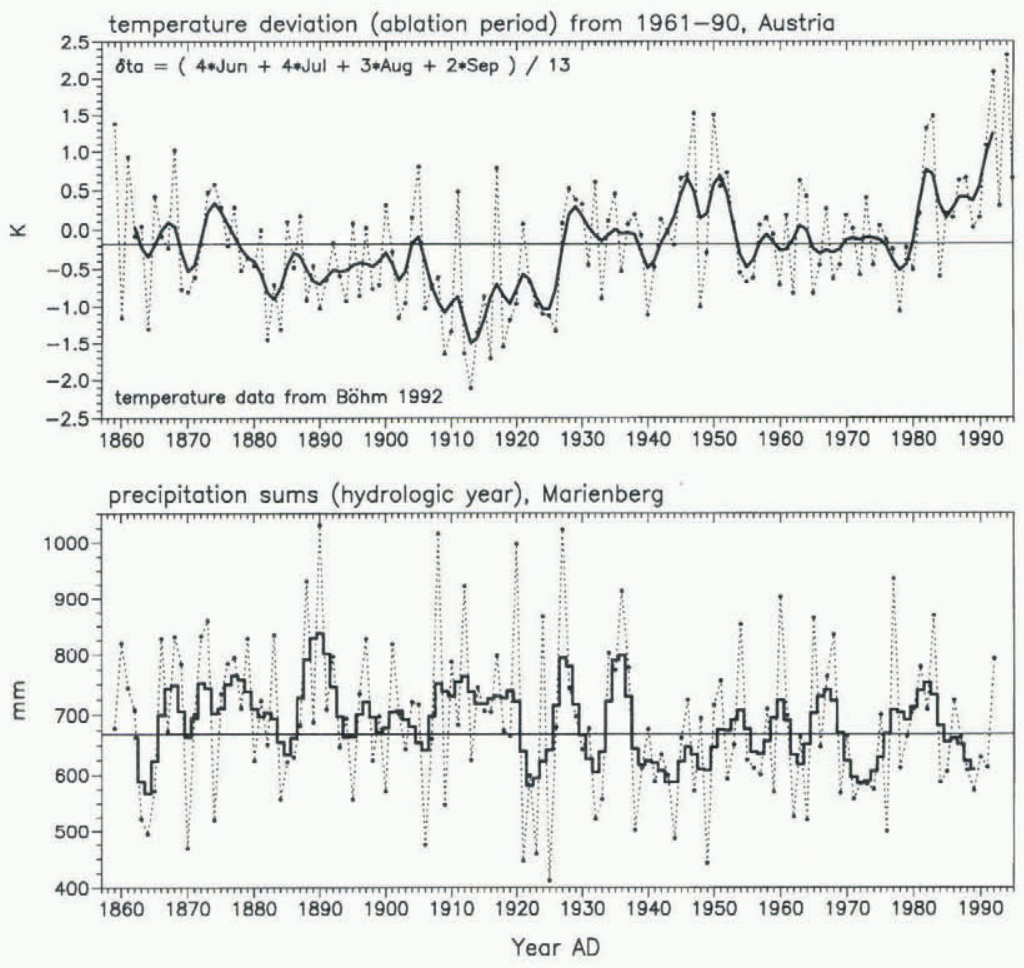

Fig. 2. "Austrian temperature deviations" for the ablation period, relative to 1961-90 (Böhm, 1992); precipitation sums (hydrologic year), Marienberg, South Tyrol.

1991, its area was $8.88 \mathrm{~km}^{2}$, the snout was at $2450 \mathrm{~m}$ and the highest point was at $3793 \mathrm{~m}$. Glaciological mass-balance measurements were started in 1952 and have continued. The ELA from 1964 onwards is particularly suited for modelling (personal communication from M. Kuhn, 1994).

The "Austrian Temperature Series" consists of monthly mean temperature deviations from the 1961-90 mean, which are calculated as weighted averages from a large number of meteorological stations all over Austria. As the individual temperature records are carefully homogenised, the "Austrian Temperature Series" is considered homogeneous (for details, see Böhm 1992; Auer and others, 1996). The published data begin in 1775. After the mid-19th century, when widespread climatological measurements began in Austria, they are definitely spatially representative. Precipitation measurements at the monastery of Marienberg in the upper Etsch valley (South Tyrol, $1335 \mathrm{~m}$ a.s.l.) started in March 1857. Monthly sums since 1858 are easily available in published form (Fliri, 1986). The big advantage of Marienberg is that it is not far south of Hintereisferner (Fig. 1). In a thorough analysis, Stuefer (1995) showed their usefulness of the study of glacier behaviour in the Ötztal massif. Continuous daily records for temperature and precipitation are missing for the first part of the discussed period. Therefore, more sophisticated methods like positive degree days, for example the "TS method" (Hoinkes and Steinacker 1975; Steinacker, 1979), cannot be used for predicting the ELA.

\section{DETERMINISTIC MODELLING}

As a first approximation, a simple version of the glacialmeteorological model by Kuhn $(1981,1989)$ can be used to calculate fluctuations of the ELA from climatic data. The results from those calculations provide a benchmark for the statistical modelling. Disregarding changes in the shortwave radiation balance and the latent heat flux, the equa- tion for ELA fluctuations is

$$
\left(\delta h=\alpha \delta T_{\mathrm{a}}+\delta A-\frac{L}{\tau} \delta c\right) /\left(\frac{L}{\tau} \frac{\partial c}{\partial z}-\frac{\alpha \partial T_{\mathrm{a}}}{\partial z}\right)
$$

where $\delta h$ is the change in the ELA, $\delta T_{\mathrm{a}}$ is the change in the mean temperature of the ablation season, $\delta c$ is the change in accumulation, $\alpha$ is the turbulent heat exchange coefficient $\left(1.7 \mathrm{MJ} \mathrm{m}^{-2} \mathrm{~d}^{-1}\right), \delta A$ is the change in atmospheric long-wave radiation $\left(\delta A=4 \sigma T^{3} \delta T_{\mathrm{a}}=0.3 \mathrm{MJ} \mathrm{m}^{-2} \mathrm{~d}^{-1} \times \delta T_{\mathrm{a}}\right.$ for $T=$ $273 \mathrm{~K}), L$ is the latent heat of fusion $\left(0.334 \mathrm{MJ} \mathrm{m}^{-2} \mathrm{~d}^{-1}\right), \tau$ is the length of the ablation season $(120 \mathrm{~d}), \delta T_{\mathrm{a}} / \partial z$ is the vertical temperature lapse rate $\left(-0.0065^{\circ} \mathrm{C} \mathrm{m}^{-1}\right)$, and $\partial c / \partial z$ is the vertical lapse rate of accumulation $\left(1 \mathrm{~kg} \mathrm{~m}^{-1}\right)$.

The temperature deviation for the ablation season $\left(\delta T_{\mathrm{a}}\right.$ :

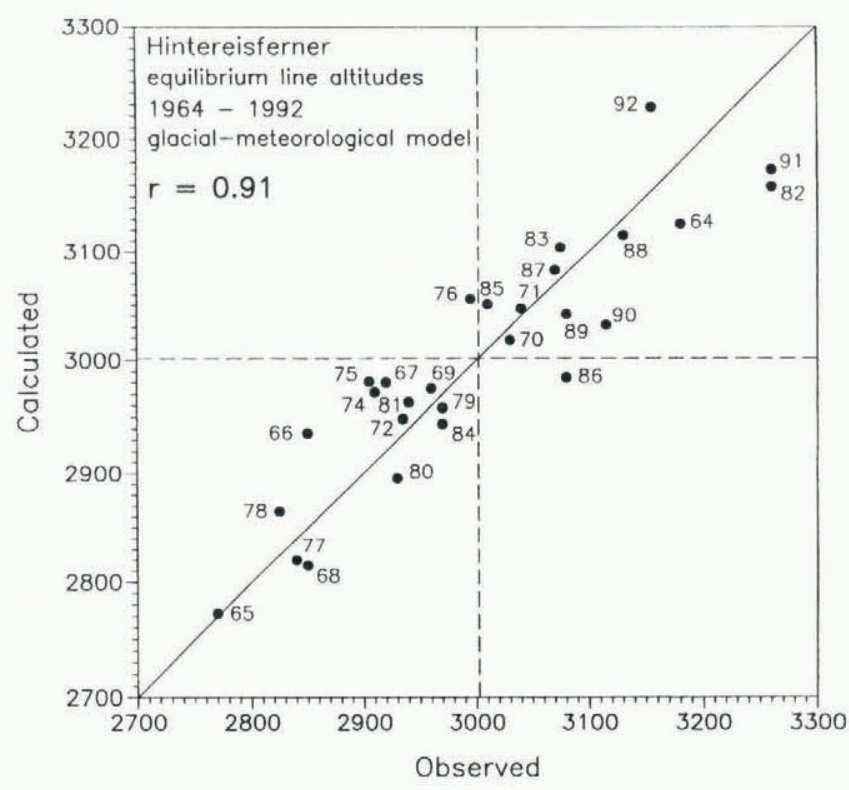

Fig. 3. Relation between observed and calculated ELAs, glacial-meteorological model (Kuhn, 1981, 1989). 
Table 3. Parameters for the multiple regression equation ("extensive" model)

(a) ELA temperature deviations

$\begin{array}{lllll}\delta T_{05} & \delta T_{06} & \delta T_{07} & \delta T_{08} & \delta T_{09} \\ 0.20 & 0.24 & 0.66 & 0.55 & 0.36\end{array}$

(b) ELA precipitation sums

$\begin{array}{llllll}p_{10-4} & p_{05} & p_{06} & p_{07} & p_{08} & p_{09} \\ -0.11 & -0.18 & 0.17 & -0.34 & -0.02 & -0.2\end{array}$

$-0.34-0.02$

$-0.23$

(c) Monthly temperature deviations and precipitation sums

May June July August September

$\begin{array}{lllll}0.063 & 0.020 & -0.227 & -0.111 & 0.004\end{array}$

Subscripts 05,06 , etc., refer to the respective months.

Fig. 2) was calculated as

$$
\delta T_{\mathrm{a}}=\frac{4 \delta t_{\text {June }}+4 \delta t_{\text {July }}+3 \delta t_{\text {August }}+2 \delta t_{\text {September }}}{13} .
$$

This kind of weighted mean also takes into account changes in day length. As accumulation around the ELA of Hintereisferner is about 2.5 times the annual precipitation at Marienberg $\left(p_{10-9}\right)$, the change in accumulation $(\delta c)$ was calculated as $\delta c=2.5 \delta p_{10-9}$ which is a rough approximation only.

Despite the rather crude calculation of ablation and accumulation, the correlation between observed and calculated deviations of the ELA is $0.91 \quad(83 \%$ of the variance explained; Fig. 3), which is not bad. With some experimental fine-tuning of the calculation of $\delta T_{\mathrm{a}}$ and $\delta c$, the correlation coefficient can be pushed towards 0.94 . This is, however, a merely statistical approach aimed at minimising correlations between $\delta h$ and monthly temperature deviations and precipitation sums without solid empirical evidence. In any case, the glacial-meteorological model tends to slightly underestimate extreme deviations (Fig. 3). This is particularly true for years with high ELAs, like 1964, 1982 and 1991.

\section{STATISTICAL MODELLING}

In an earlier paper, daily temperature data from the Sonnblick observatory ( $3106 \mathrm{~m}$ ) were used to model ELA fluctuations of Hintereisferner (Kerschner, 1996). The resulting multiple regression equation was fairly complicated, and during the calculation of the parameters numerous numerical problems had to be faced. In this case, only monthly mean temperature deviations and precipitation sums were used, and no problems were encountered during the calculation of the parameters of the regression equations. This empirical evidence suggests that regional averages of temperature are better suited for this kind of modelling than observations from a single mountain-top station.

Table 2. Parameters for the multiple regression equation ("simple" model)

\begin{tabular}{lccc}
\hline Variable & $B$ & $\beta$ & Significance \\
& & & \\
\hline$\delta t$ June & 58.3 & 0.438 & 0.0001 \\
$\partial t$ July & 42.3 & 0.416 & 0.0004 \\
$\partial t$ August & 38.4 & 0.419 & 0.0003 \\
$\partial t$ September & 22.8 & 0.237 & 0.0168 \\
$p$ October-September & -0.541 & -0.476 & 0.0000 \\
Constant & 3351.4 & & \\
& & & \\
\hline
\end{tabular}

\begin{tabular}{lccc}
\hline Variable & $B$ & $\beta$ & Significance \\
\hline$\delta t$ June & 53.2 & 0.399 & 0.0000 \\
$\delta t$ July & 62.7 & 0.616 & 0.0000 \\
$\delta t$ August & 18.4 & 0.201 & 0.0049 \\
$\delta t$ September & 27.0 & 0.281 & 0.0001 \\
$p$ October April & -0.262 & -0.147 & 0.0248 \\
$p$ May & -0.948 & -0.353 & 0.0000 \\
$p$ July & -1.130 & -0.308 & 0.0000 \\
$p$ August & -4.007 & -1.337 & 0.0000 \\
$p$ August (squared) & 0.018 & 1.152 & 0.0001 \\
$p$ September & -0.515 & -0.178 & 0.0054 \\
Constant & 3438.7 & & \\
& & & \\
\hline
\end{tabular}

Although regression modelling is a purely stochastic technique and, therefore, a black-box-approach, the variables chosen should at least be physically meaningful. Ideally, there should be some correlation between the dependent and the independent variables and no correlation between the independent variables. Table 1 shows that this is actually the case.

The general form of such a multiple linear regression equation is

$$
\mathrm{ELA}=B_{1} V_{1}+B_{2} V_{2}+\ldots, B_{n} V_{n}+\text { constant }(+ \text { error })
$$

where the regression coefficient $B_{n}$ is the weight of the variable $V_{n}$. The relative importance of the variables can be checked with the standardised regression coefficient $\beta$, which shows by how many standard deviations the dependent variable (in this case, ELA) changes, if the respective independent variable changes by one standard deviation. These coefficients may, however, also contain information about combined and "hidden" effects and must not be interpreted in a physical sense. Data selection and calculation of the parameters was done with the "regression" routine of SPSS/PC+ software. It calculates the parameters for a least-squares approximation, attempting an optimisation of the multiple correlation coefficient and the exclusion of nonsignificant variables.

As a first approach, the same variables as in the glacial-

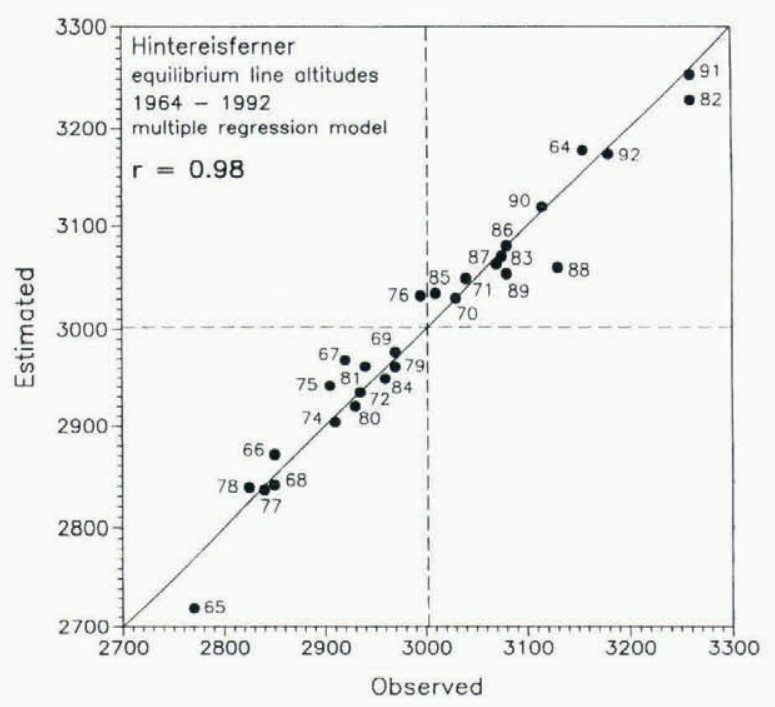

Fig. 4. Relation between observed and estimated ELAs, multiple regression model. 


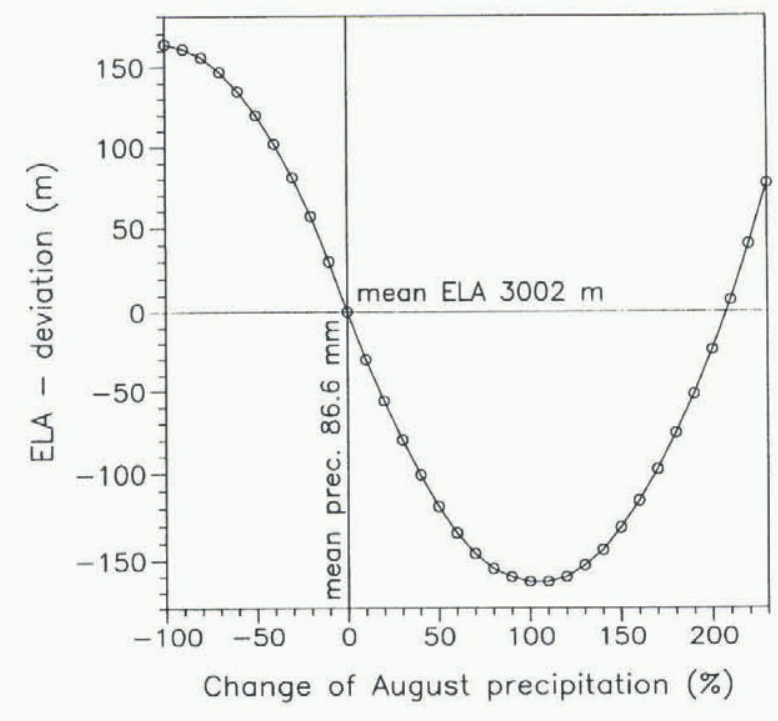

Fig. 5. Relative importance of August precipitation (all other variables kept at mean values) for the ELA of Hintereisferner.

meteorological model were used. The multiple correlation coefficient is 0.91 , as above. The model parameters are listed in Table 2. Final calculations started with a standard set of data (temperature deviations May-September: $\delta t_{05}, \ldots$, $\delta t_{09}$; precipitation sums for winter and May-September: $p_{10-4}$ and $\left.p_{05}, \ldots, p_{09}\right)$. First results showed that the inclusion of squared August precipitation sums $\left(p_{08 s q}\right)$ leads to a significant improvement of the multiple correlation coefficient (see below). The variables included in the equation are listed in Table 3. A multiple correlation coefficient of 0.98 was easily achieved with $94 \%$ of the ELA variance explained (Fig. 4). More than $50 \%$ of the residuals are less than $\pm 20 \mathrm{~m}$, and their standard deviation is $25 \mathrm{~m}$. The maximum residuals are $70 \mathrm{~m}$ (1988) and $50 \mathrm{~m}$ (1965).

As can be seen from Table 3 , the variables with the highest relative importance are the temperature deviations of
June and July and the precipitation of May. Whereas increasing values of July precipitation lead to a lowering of the ELA, the role of August precipitation (variables $p_{08}, p_{08 s q}$ ) varies (Fig. 5). Increasing precipitation sums first lead to a lowering of the ELA, but when August precipitation is more than double the average, the ELA begins to rise rapidly. This effect is probably caused by extreme precipitation events as in 1987, associated with the massive advection of warm air from the Mediterranean. Then temperatures are so high that precipitation falls as rain on the entire glacier, thus significantly reducing the surface albedo. Generally, summer precipitation in the context of a stochastic climate-glacier model should be regarded not so much as a contribution to accumulation, but rather as a variable describing "bad" or "good" weather conditions, with consequences for the short-wave radiation balance of the glacier surface.

As the "Austrian Temperature Series" goes back to 1775, it seemed to be promising to calculate the parameters for a "temperature-only model" as well. Unfortunately, this proved to be a complete failure. The multiple correlation coefficient for a model including temperature deviations for May-September was only 0.75 . On the other hand, this result shows the importance of precipitation sums as additional predictors for the calculation of ELAs, although they are not individually correlated to ELA fluctuations (Table 1).

\section{RESULTS}

The results of both the glacial-meteorological model and the statistical model are rather similar (Fig. 6a and b). However, as the correlation coefficient between observed and predicted ELAs is better for the multiple regression model, the interpretation relies mainly on the results of the statistical approach. Both figures show not only the annual values, but also a 10 year unweighted running average, which is centred at the last year of each period (cf. Patzelt, 1977). If $\mathrm{RA}_{\mathrm{ELA}(i)}$ is the running average of the ELA in year $(i)$, it is
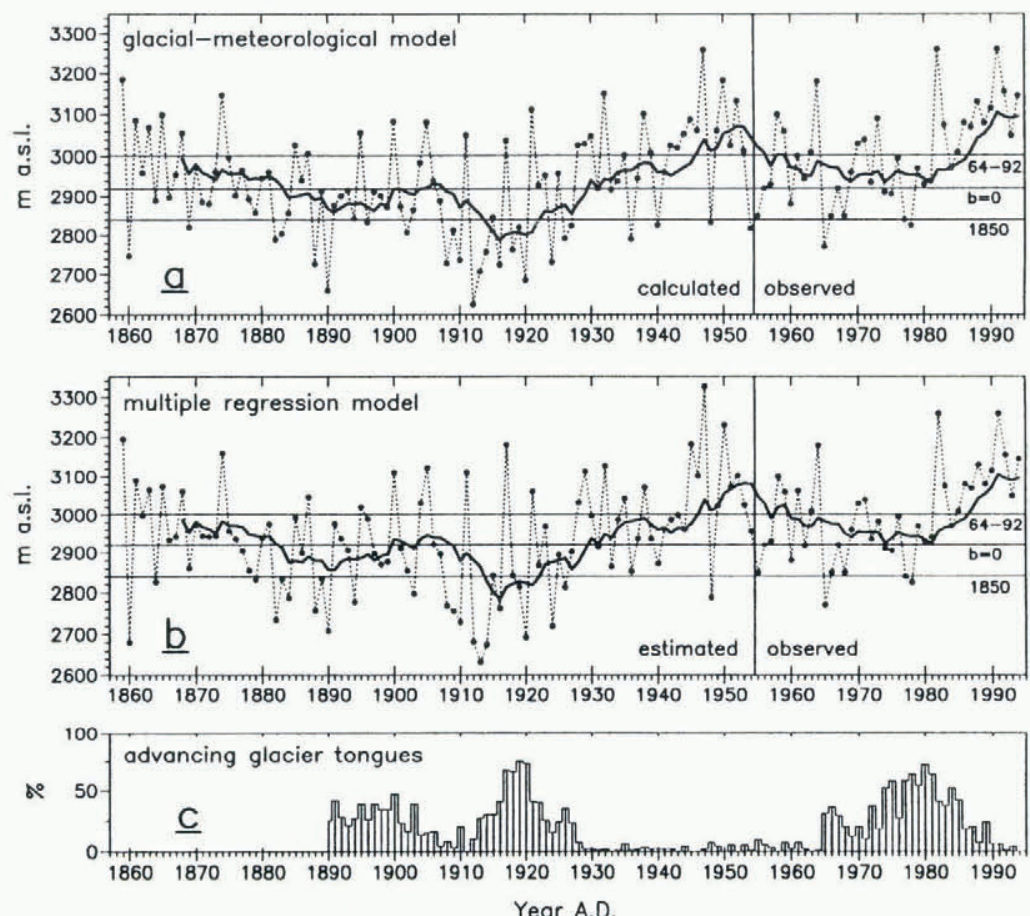

Fig. 6. Annual ELAs as calculated with (a) the glacial meteorological model, (b) the multiple regression model, (c) percentage of advancing glacier tongues in the Austrian Alps (after Patzelt 1970, 1977, written communication, 1995). 
calculated as

$$
\begin{aligned}
& \mathrm{RA}_{\mathrm{ELA}(i)}= \\
& \underline{(\mathrm{ELA}(i)+\operatorname{ELA}(i-1)+\operatorname{ELA}(i-2)+\ldots \operatorname{ELA}(i-9)}
\end{aligned}
$$$$
10
$$

As reference altitudes, ELAs of 2850 and $2920 \mathrm{~m}$ can be used. The former is the mean ELA of the mid-19th-century maximum ("1850"), and the latter is the ELA for $b=0$ for the present-day extent of Hintereisferner. The reconstructed ELAs start shortly after the "1850" glacier maximum, which, in the case of Hintereisferner, was probably reached just before 1860 (Nicolussi, 1995). In 1859 the ELA (3200 m) was among the highest values of the entire period, and it remained at high altitudes until the late 1870s. It then showed a tendency to fall, and fluctuated around a rather low average position during the last decades of the 19th century, remaining, however, above $2850 \mathrm{~m}$ for most of the time. This changed during the first decade of the 20th century, when low ELAs became more frequent. During the years 190726, the ELA of Hintereisferner was lower than the "1850" average in 13 out of 20 years. The lowest ELAs of the entire period were reached in $1912(2680 \mathrm{~m}), 1913(2630 \mathrm{~m})$ and 1914 $(2680 \mathrm{~m}), 170-220 \mathrm{~m}$ lower than the " 1850 " average. Summers in the years after the eruption of Katmai volcano not only were cold, but also brought frequent snowfalls. This led finally to the marked advance of the 1920 s, which was widespread in the Alps (Patzelt, 1970, 1973; Fig. 6c). The Hintereisferner advance started in 1917 and ended in 1922. By 1930, the 10 year running average was higher than $2920 \mathrm{~m}$ and it has remained there. As a result, the advance of the 1920 s was rapidly halted and a period of pronounced recession began. The highest position of the entire period was reached in $1947(3330 \mathrm{~m})$, and has not been reached since even in the early 1990s. Reports from that year say that most glaciers were completely snow-free by the end of summer. Seemingly, this was due not only to high summer temperatures (see Fig. 1), but also to very dry conditions. After the early 1950 s, a tendency towards lower values can be observed, which lasted until 1980. Average values, however, did not fall below $2920 \mathrm{~m}$. As a consequence, the recession of Hintereisferner continued, whereas other glaciers in the Alps readvanced for a short period of time (Patzelt, 1985). Since 1982, average values have again been very high.

\section{CONCLUSIONS}

Both the glacial-meteorological and the statistical approach to the reconstruction of former ELAs of Hintereisferner from simple climatic data yield good results. Not only are they well supported by high correlation coefficients between observed and estimated values, but there is also good qualitative agreement with the dendroclimatological reconstruction of former mass balances of Hintereisferner (Nicolussi, 1995) and the general history of recent glacier fluctuations in the Alps (e.g. Patzelt, 1970, 1973). At least since the mid-19th century, when a large number of climatic stations was established in the eastern Alps, the "Austrian Temperature Series" has been a reliable data source for palaeoglaciological studies in the central Alps. If additional information about accumulation conditions can be obtained from precipitation measurements, the modelling results are significantly improved.

The results show that, after the "1850" glacier maximum, ELAs fluctuated around rather low altitudes for some decades, dropping to very low altitudes again in the years around World War I. Parallel to the trend in temperature, they rose to higher values in the late 1920s. Therefore, it would seem to be reasonable to date the end of the "Little Ice Age" in the Alps to the late 1920s. The period between the late 1920s and the early 1960s was the longest period of almost constantly high ELAs since the mid-19th century.

\section{ACKNOWLEDGEMENTS}

I should like to express thanks to M. Kuhn, E. Dreiseitl and G. Markl (Institut für Meteorologie, Innsbruck) for providing mass-balance data set for Hintereisferner, to G. Patzelt (Forschungsinstitut für Hochgebirgsforschung, Innsbruck) for supplying data on advancing glacier tongues in Austria, to R. Böhm (Zentralanstalt für Meteorologie und Geodynamik, Vienna) for providing the most recent version of the "Austrian Temperature Series", and to G. Kaser (Institut für Geographie, Innsbruck) and K. Nicolussi (Forschungsinstitut für Hochgebirgsforschung, Innsbruck) for frequent discussions on the topic. Valuable comments by reviewers (C. Raymond and P. Holmlund) are greatly appreciated.

\section{REFERENGES}

Auer, I., R. Böhm and H. Mohnl. 1996. Zusammenfassung über den Stand der Forschung auf dem Gebiet der Zeitreihenanalyse instrumenteller klimatologischer Meßdaten. ÖGM-Bulletin 96/1, 1-15.

Böhm, R. 1992. Lufttemperaturschwankungen in Österreich seit 1775. Österreichische Beiträge zur Meteorologie und Geophysik 5.

Fliri, F. 1986. Beiträge zur Kenntnis der jüngeren Klimaänderungen in Tirol. Niederschlagsbeobachtungen an der Universität Innsbruck 1981 bis 1985 und im Kloster Marienberg 1858 bis 1985. Innsbrucker Geographische Studien 15.

Hoinkes, H. 1970. Methoden und Möglichkeiten von Massenhaushaltsstudien auf Gletschern: Ergebnisse der Meßreihe Hintereisferner (Ötztaler Alpen) 1953-1968. Z. Gletscherkd. Glazialgeol., 6(1-2), 37-90.

Hoinkes, H. and R. Steinacker. 1975. Hydrometeorological implications of the mass balance of Hintereisferner, 1952 53 to 1968-69. International Association of Hydrological Sciences Publication 104 (Symposium at Moscow 1971 - Snow and Ice), 144-149.

Kerschner, H. 1996. Multivariate statistical modelling of equilibrium line altitudes: Hintereisferner (Ötztal) - Stubacher Sonnblickkees (Hohe Tauern). Z. Gletscherkd. Glazialgeol., 32, Part 2, 1995, 119-127.

Kuhn, M. 1978. Correspondence. On the non-linearity of glacier length response to climatic changes: comments on a paper by H.W. Posamentier. 7. Glaciol., 20 (83), 443-446.

Kuhn, M. 1981. Climate and glaciers. International Association of Hydrological Sciences Publication 131 (Symposium at Canberra 1979 - Sea Level, Ice and Climatic Change), 3-20.

Kuhn, M. 1989. The response of the equilibrium line altitude to climatic fluctuations: theory and observations. In Oerlemans, J., ed. Glacier fluctuations and climatic change. Dordrecht, etc., Kluwer Academic Publishers, 407-417.

Nicolussi, K. 1995. Jahrringe und Massenbilanz: dendroklimatologische Rekonstruktion der Massenbilanzreihe des Hintereisferners bis zum Jahr 1400 mittels Pinus cembra-Reihen aus den Ötztaler Alpen. Z Gletscherkd. Glazialgeol., 30, 1994, 11-52.

Ohmura, A. 1990. On the existence of Glacier No. 1, Ürümqi River. Zürcher Geogr. Schr., 38, 37-42

Ohmura, A., P. Kasser and M. Funk. 1992. Climate at the equilibrium line of glaciers. 7. Glaciol., 38(130), 397-411.

Patzelt, G. 1970. Die Längenmessungen an den Gletschern der österreichischen Ostalpen 1890 bis 1969. Z. Gletscherkd. Glazialgeol., 6(1-2), 151-159.

Patzelt, G. 1973. Die neuzeitlichen Gletscherschwankungen in der Venedigergruppe (Hohe Tauern, Ostalpen). Z. Gletscherkd. Glazialgeol., 9(1-2), 5-57.

Patzelt, G. 1977. Statistik der Längenmessungen an den österreichischen Gletschern 1960 bis 1975. Z Gletscherkd. Glazialgeol., 12(1), 1976, $91-94$.

Patzelt, G. 1985. The period of glacier advances in the Alps, 1965 to 1980 . Z. Gletscherkd. Glazialgeol., 21, 403-407.

Steinacker, R. 1979. Rückrechnung des Massenhaushaltes des Hintereisferners mit Hilfe von Klimadaten. Z. Gletscherkd. Glazialgeol., 15(1), 101-104.

Stuefer, M. 1995. Der unterschiedliche Einfluß des Klimas auf die Gletscher der Ötztaler Alpen und der Silvrettagruppe. (Diplomarbeit in Meteorologie, Universität Innsbruck.) 